\title{
TADALURING Microteaching Learning Model (TMLM): Preparing Professional Teacher by Pre-Service Training
}

\author{
Arifmiboy $^{1 *}$, Jamaris Jamna ${ }^{2}$, \\ Mega Iswari $^{2}$, and Agustina ${ }^{2}$ \\ ${ }^{1}$ Institut Agama Islam Negeri Bukittinggi (IAIN Bukittinggi) \\ ${ }^{2}$ Universitas Negeri Padang (UNP)
}

\begin{abstract}
As a certified professional, teacher forms indispensable roles in achieving the learning objectives. The complexity of teacher's profession decidedly requires the teacher to master a number of competencies and skills. One of them is to master the basic teaching skills. Realizing the complexities of the teacher's profession and the requirement of teacher's profession, LPTK -Faculty of Teacher Training and Education- which produces professional teacher, requires enhancing the teacher's quality and creativity through pre-service teaching and training. Microteaching is one of the efforts to prepare the candidate for a professional teacher in higher education. The growth of a number of students being served with the availability of micro teaching laboratories is, however, disproportionate. Consequently, the problems faced are the time management, the laboratory utilization, the availability of sufficient microteaching infrastructures as well as the implementation of micro teaching itself. One of the ways to solve the problems is to develop a microteaching model adapting the force driving sophisticated ICT named TADALURING Microteaching Learning Model (TMLM). The Instructional Systems Design (ISD) made use of developing the model is Borg and Gall procedures. The cyclical phases of conducting the research were preliminary research, development, fieldtesting, and dissemination. The research finding indicates that the trialtested model is stated valid, practical, and effective. The TADALURING Microteaching Learning Model (TMLM) is essentially accentuated on a face-to-face classroom, online and offline practices.
\end{abstract}

Key Words: micoreaching, model, tadaluring

\section{Introduction}

The International surveys' results reported that quality of Indonesian education still extremely declines. The 1997 to 2007 World Competitiveness Year Book's survey reported that of the 47 countries surveyed, Indonesia ranked $39^{\text {th }}$ in 1997 and $46^{\text {th }}$ in 1999 . Then in 2002 , of 49 countries surveyed, Indonesia ranked $47^{\text {th }}$ and in 2007 , of the 55 countries surveyed, it still ranked $53^{\text {rd }}$ [1]. Similarly, in 2005, A Global Monitoring Report released by UN agency, UNESCO, Indonesia ranked $10^{\text {th }}$ among 14 developing Asia Pacific's countries [2]. Another international survey, The United Nations Development Program (UNDP) reported that the Indonesian's Human Resource Quality ranked $109^{\text {th }}$ out of 177 countries in the world [3]. Meanwhile, The Political and Economic Risk (PERC) Consultancy Agency in Hongkong informed that the quality of education in Indonesia still extremely declines among 12 Asian countries studied. This indicated that the quality of

*Corresponding Author: arifmiboy@yahoo.co.id 
education in Indonesia drew level with Honduras and Nigeria although it is better than the Vietnam.

At the praxis level, the educational problems designate the obstacles to realistically achieving the goals of national education as legally mandated in the Law No. 20 of 2003 on the National Education System. The declining quality of Indonesian Human Resources (HR) becomes one of the real causes of the obstacles. The decline can be analyzed from several macro indicators, among others, are the 2008 to 2009 Global Competitiveness Report from the World Economic Forum in Martin stating that Indonesia ranked $55^{\text {th }}$ out of 134 countries in terms of the achievement of Competitiveness Index (CI). Subsequently, the United Nations for Development Program in Human Development's 2007/2008 research results reported that Indonesia ranked at the $107^{\text {th }}$ of 155 countries in terms of Human Development Index's (HDI) achievement [4].

The declining quality of Indonesian education had been clearly elucidated by the Study Program for International Student Assessment (PISA) in 2003. PISA reported that, for Science and Mathematics literacy, 15-year-olds ranked $38^{\text {th }}$ out of 40 participating countries and for reading literacy, Indonesian students ranked 39th. In 2006, the reading literacy achievement of Indonesian students ranked 48th out of 56 countries while mathematical literacy ranked 50th out of 57 countries, and science literacy ranked 50th of 57 countries. Furthermore, in 2006, the Progress in International Reading Literacy Study's (PIRLS) research report on the grade 4 elementary school children's reading literacy worldwide under the coordination of The International Association for the Evaluation of Educational Achievement (IEA) in 45 countries/states, both from developed countries and developing countries, found that Indonesian students ranked $41^{\text {st }}$ out of 45 participating countries [5].

Similarly, Balitbang's Data indicated that quality of Indonesian education extremely devastated. The data explained that 8 of 146,052 elementary schools nationwide which has been internationally recognized as The Primary Years Program (PYP). Similarly, 8 of 20,918 Indonesian Junior High Schools which has been internationally recognized as The Middle Years Program (MYP) and lastly, 7 out of 8,036 Senior High Schools which have been internationally recognized as The Diploma Program (DP). The results of the Teacher Competency Test (UKG) held by the Ministry of Education and Culture in November 2015 were still beneath the expected standards. As disclosed by the former Minister of Education and Culture, Mr. Anis Baswedan, PhD, “the average national UKG's score exceptionally declined. The average of national UKG's score was 53.02, whereas the government targeted the average score was at 55. In addition, the average professional competence's score was 54.77 while the pedagogic competence's score was 48.94 " [6].

In response to the aforementioned conditions, it requires central government and stakeholders' efforts to improve the quality and competence of Indonesian teachers. These efforts and improvements will automatically assist the achievement and accomplishment of Indonesian education. The process of enhancing Indonesian teachers' professionalism must be early begun when the prospective teachers are studying in university (pre-service). As prospective teachers, the students should possess, experience, and master a variety of courses related to pedagogic competence such as learning planning, learning strategies, instructional media, curriculum development, educational psychology, and learning evaluation. All of these courses will provide pieces of fundamental educational knowledge to prospective teachers in the context of enhancing their pedagogic competence. One of the efforts that can be undertaken to develop the teachers' pedagogic competence is the process of educational training that is packaged in a micro teaching course. Theoretically, Dwight Allen clearly explicated that the primary goal of micro learning is to separately provide the real learning experiences, practices and some indispensable teaching skills to the 
prospective teachers. They are expected to develop their teaching skills prior to teaching at the real classroom setting [7].

The development of the sophisticated information technology in the field of education opens an access or provides opportunities to undertake the long distance education using the internet media to connect the students with the lecturers, access college schedule, check finances, and send the task files and or documents given by teachers and so on. Everything can be easily done online. Taking into account of the problems faced in microteaching learning along with the development of ICT's facilities, there is a call for developing a Model of Microteaching Learning adopting the today's technological developments as a realistic solution to the problems.

\section{Literature Review}

Conceptually, the "microteaching" stems from two words, namely micro and teaching. Micro means small, limited, and narrow, while teaching means educating or teaching. Allen and Ryan in Lakshmi explicate that microteaching as a scaled down teaching encounter, scale down in term of class size, lesson, length, and teaching complexity [8]. Whereas Allen point out that "microteaching as a system of controlled practice that make it possible to concentrate on specific teaching skills and to practice teaching under controlled conditions" [9]. Singh states that microteaching is a training technique, which requires pupil teachers to teach a single concept, using specified teaching skills to a small number of pupils in a short period of time [10].

Cooper and Hillary affirm that microteaching forms a teaching situation undertaken in very limited time i.e., for 5-20 minutes with 3 to 10 students [11]. Furthermore, Mc. Laughlin and Moulton describe microteaching is a performance training method designed to isolate the component part of teaching process, so that the trainee can master each component one by one in a simplified teaching situation. Lakshmi adds, microteaching is a scaled-down teaching encounter' in which a teacher teaches a small unit to a group of 5 to 10 pupils [12]. Barmawi highlights that the difference between microteaching and teaching in terms of the number of students. In microteaching class, it comprises of 5 to 10 students whereas in teaching, it includes 30 to 40 students. In conclusion, microteaching is an extremely controlled teaching training to master certain basic teaching skills in a minimised learning condition in terms of time, materials, skills, and a number of students [13].

Dwight Allen explains that the purpose of microteaching for prospective teachers is to: 1) provide real teaching experience and practice a number of basic teaching skills, 2) the prospective teachers can develop their teaching skills ahead of entering the field; and 3) provide a variety of basic teaching skills. For teachers themselves, it refreshes educational programs, and expands teaching experience individually to develop professionalism, and build up an open attitude for teachers to innovation [14].

Wight Allen describes the implementation of microteaching done through seven stages. The six stages of microteaching form a cycle and they can be repeated in accordance with meeting the needs for improvement. The followings are the steps of microteaching learning.

1. Planning a micro-lesson determines the right subject matter that maximizes the practice of teaching skills within 5 to 7 minutes.

2. The teaching session is a lesson plan implemented in front of mentors or classmates. The performance of teachers who practice teaching skills is observed and recorded. The evaluation sheets, tape recorders, and/or video tapes can be used for such purposes. 
3. The critique session is the lecturer and the participants discuss the performance of the trainees. Feedback and key points are communicated to the trainees for selfimprovement. Evaluation tools provide an opportunity for micro teachers to view their performance objectively. The micro-participants are not given the opportunity to question for self-defence. This is the strength and uniqueness of microteaching

4. The re-planning session is a micro participant develops a teaching plan based on the feedback offered in the critique session. The time provided for this stage is 5 to 7 minutes

5. The re-teaching session is a step to provide the opportunity for micro participants to teach the same unit and skills. Nevertheless, of course, the performance of the micro-teacher, in this session, should have paid attention to the mentors and/or peers' feedbacks. In this session, supervisors and peers evaluate the performance of the participants who perform using the observation sheet.

6. The re-critique session is the same procedure adopted as mentioned in the critique session. The micro participant gets feedback and knows how far the improvement is. This step has the potential to motivate micro participants to improve their appearance in the future [19].

\section{Methodology}

The Borg and Gall's Instructional Systems Design forms the 4 pieces most important cycles in developing the TADALURING model. In general, in developing the model, TADALURING, it has four main stages. They are 1: Preliminary Research, Stage 2: Model development, stage 3, Field test or model validation and, stage 4: dissemination The stages of developing the model were the combination of a planning along with Preliminary research results, relevant research, and literature study served as the basis for the preparation of microteaching model TADALURING. The stages of learning model development included some of the following activities.

1. Drafting and or composing the design of the model. The basic drafting and or composing of this design used was the preliminary study, the foundation of learning theories, the theory of model development, and the feasibility of its implementation.

2. Experts' validation and practitioners. To validate the design of the developed model was undertaken through experts' judgments. The experts who had been involved were Prof. Dr. Harris Effendi Thahar, M. Pd as a linguist, Dr Jsrial, M. $\mathrm{Pd}$ as the design expert, Dr H. Darul Ilmi as a material expert, Dr Asrul Huda, M. Kom as a media and ICT's expert, and Dr Ir. Khairani, M. Pd as an evaluation and instrument's expert. The instruments used in conducting the feasibility test were the validation sheets for the experts. The validated components were language, developed model structure, teaching preparation, basic teaching skills, observation sheets, questionnaires, observation checklists, and interview guides. Every expert had provided insight and input regarding the design of the developed model. The inputs and suggestions had been used as a basis for the draft revisions of the designed model. More importantly, the researchers had used validation sheets which could shape the revision processes of the designed model. The result generated the hypothetical design that has been tested on subsequent activities.

3. Revising the draft of the designed model. The revised draft of the designed model referred to the suggestions and inputs on the desk evaluation comprised of the experts' validation sheets. 
The developed TALALURING microteaching-learning model was validated by a number of experts in their respective fields (experts' validation). The expert validity was undertaken in order to obtain the theoretically, substantially, and methodologically experts' recognition. Experts in question are design, linguists, microteaching learning materials, and ICT media experts. Validated objects are instruments, model books, and learning tools. The resutl showed an average score of 3.72 and validly interpreted.

The effectiveness test was undertaken in the form of quasi-experiment research with Non-Equivalent Group Design.. The experiment was given to 24 students in the English Department of teacher training Faculty of IAIN Bukittinggi the seventh semester of 2016/2017 academic year. Adapting to the research design model used, the researcher divided the samples into two groups comprising of 12 participants tailoring to the amount of set by the study programs for each study group in microteaching lectures. The sample used was accidental technique. Based on the pre-test and post, the gained avarage scores were 14. 10. Besides, the hyphothesis which suggested that the mean's score of the mastery of the basic teaching skills is higher then 80, is accepted. The score of $t_{\text {obtain }}>t_{\text {table }}$ $(2,065>1,711)$.

The practicality's test involved three universities namely IAIN Bukittingi, IAIN Batusangkar, and UIN Imam Bonjol Padang. The number of lecturers involved was 15 people with different areas of expertise. The result showed that an average score of 83,53 and effecftively interpreted.

\section{Result}

The Tadaluring is the acronym of a face-to-face, inside and outside the network. Tadaluring Microteaching Learning Model (TMLM) is a learning model that combines the forms of teaching practices in an integrated way using communication technology media. These combinations form the face-to-face classroom's practice, face-to-face Online's practice, and face-to-face offline's practice.

Tadaluring microteaching learning model is classified into a family behaviour modification model. In the behaviour modification models are also known a number of model namely; Contingency management model, self-control model, training model, stress reduction model, desensitization model, and assertiveness training model. From a number of various branches of the model, the microteaching Tadaluring learning model includes training model. The construction of the micro teaching course flow is illustrated as follows.

Figur 2. Tadaluring Microteaching Learning Model

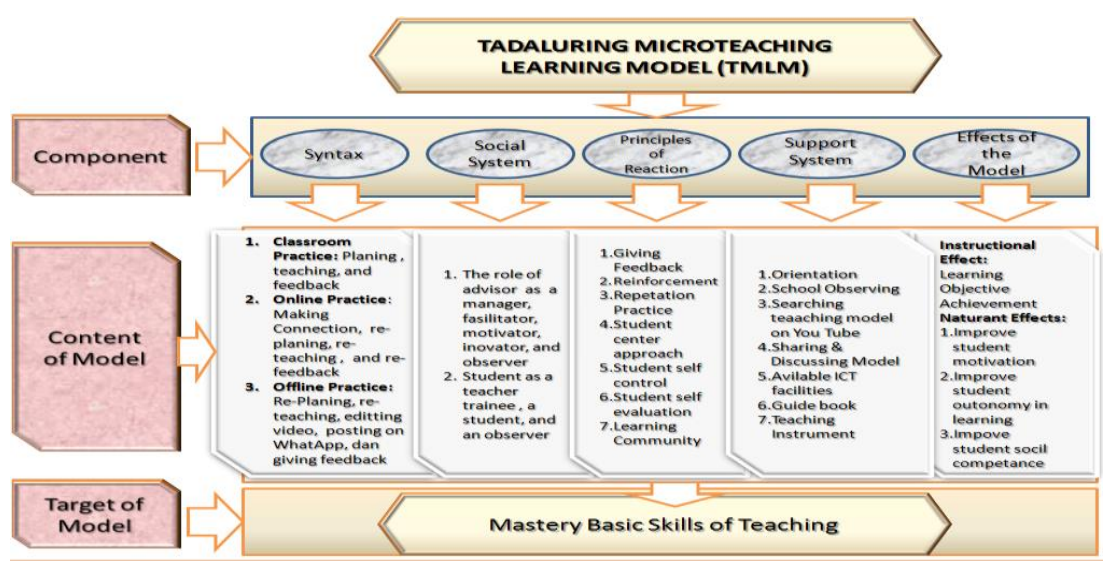


Based on the above diagram, it can be understood that the Tadaluring microteachinglearning model is based on the syntax components, social systems, principles of reaction, support system, and effect of the model. The details are elucidated as follows.

\section{1. Syntax}

The syntax of Tadaluring microteaching-learning model is described as follows.

\section{1. 1. Classroom Practice}

The classroom practice is a teaching practice activity undertaken in the classroom directly attended by supervisors and trainees in microteaching learning. The steps of teaching practice in the classroom are planning, teaching, and providing feedback. The planning activity is an activity in formulating the training strategy, such as determining the type of skills trained, determining the topic of discussion, method, learning approach, and the form of students' engagement and participants.

\section{a. Online Practice}

In-class practice activities continued with the online practice. Online practice is a practice activity carried out online with the help of means of communication over the Internet using Skype facility. With Skype facility allows supervisor and all participants can interact directly at the same time and different places. All participants and supervisors meet directly on their computer screens. Each participant and lecturer can see and greet each other.

\section{1. 2. Offline Practice}

Offline practice is a follow-up activity of online classroom practice. Offline practice is the practice of teaching activities conducted independently by involving several students or colleagues as a media in the project. Offline practice places emphasis on maximizing opportunities for practice. Each participant recorded his or her training activities independently of both basic and integrated teaching basic teaching training.

\section{2. Social System}

In the Tadaluring microteaching learning model, the role of the student is more dominant than the supervisor. The role that students play in microteaching learning is as a practising teacher, as a student in other conditions, and as an observer or evaluator. Students as teachers in microteaching learning when they practice mastering the basic skills of teaching, they will act as real teachers, starting from planning lessons, strategizing, choosing media, methods, implementing learning to carry out the evaluation.

On the other hand, the students will also act as students. Students as microteaching participants will behave and act like a student, ask questions, carry out teacher commands, answer teacher questions, hear explanations, and write various materials presented in accordance with the conditions that other participants who are practising as teachers.

Furthermore, the student as a microteaching participant is an observer as well as an assessment team. As an observer, the student will observe every gesture and learning process conducted by his colleague and then provides an assessment through the observation sheet prepared by participants who perform the practice. Even students will also provide comments in the form of suggestions and criticisms that are constructive in order to improve the appearance for the next exercise.

In Tadaluring microteaching-learning model, supervisors have a very important role in realizing learning goals. The supervisor is the director and the actor in charge. The role of lecturers is a demonstrator, facilitator, motivator, innovator, inspiratory and evaluator/observer. 


\section{3. Principels of Reaction}

In Tadaluring microteaching-learning, there are a number of reaction of principles namely repetition and improvement, giving immediate feedback either directly or indirectly, giving both verbal and non-verbal reinforcement, providing motivation, studentcentred learning, self-evaluation, and learning Independent.

\section{4. Supporting System}

Tadaluring microteaching-learning model can be done effectively if it meets a number of activities and the availability of other supporting facilities are orientation, school observing, searching teaching model on You Tube, sharing and discussing, available ICT facilities, guide book, and teaching instrument..

\section{5. Nurturant Effect of the Tadaluring Microteaching Learning Model}

Tadaluring Microteaching Learning Model provides two forms of Effects. The first is direct effect. The Tadaluring Microteaching Learning Model is able to achieve the goal of microteaching learning itself. The students of microteaching participants are able to master a mixture of basic teaching skills trained. Second is indirect effect. The indirect effects can improve student's learning motivation, student's learning independence, and students' social competence such as cooperation, mutual respect, mutual help, and reminds well behaved.

\section{Conclusion}

In respond to the force driving ICT and the difficulty in microteaching learning process, the learning model, which adopts the ICT development into microteaching learning process, is considered as a practical and effective solution to microteaching's problem or difficult situation. This is a way of dealing with it so that the difficulty is removed. Tadaluring Microteaching Learning Model (TMLM) emphasizes on learning process optimizing classroom, online and offline practice by each participant using some kinds of ICT facilities. Tadaluring Microteaching Learning Model (TMLM) was stated valid, effective and practice in using.

\section{Reference}

1. Martin, Xavier, Sala. The Competitiveness Index: Measuring the Productive Potential of Nations. In The Global Competitiveness Report 2008-2009, 15 (2008)

2. Martin, Michael O., Mullis. TIMSS 2007:International Science Report. Chestnut Hill, MA: Boston College, 5 (2008)

3. HDI. http://en.wikipedia.org/wiki/List_of_countries_by_Human_Development_Index. "List of countries by Human Development Index",15 (2008)

4. Martin, Michael O., Mullis. TIMSS 2007: International Science Report. Chestnut Hill, MA: Boston College. (2008)

5. Program for International Student Assessment (PISA), (2003)

6. www.okezone.com (04/01/16).

7. Allen, Dwight., Kevin Ryan. Microteaching. Addison-Wesley Publishing Company Inc. Reading, Massachusetts Menlo Park, California, 15 (1969)

8. Lakshmi, Majeti Jaya. Microteaching and Prospective Teachers. Discovery Publishing House Pvt. Ltd. Sachin Printers New Delhi, 4 (2009) 
9. Allen, Dwight., Kevin Ryan. Microteaching. Addison-Wesley Publishing Company Inc. Reading, Massachusetts Menlo Park, California, 29 (1969)

10. Singh, L. C. Microteaching: An Innovation in Teacher Education. New Delhi, NCERT, 25 (1979)

11. Cooper, Hillary. The Teaching of History Implementing The National Curriculum. London: Davis Fulton Publishers, 85 (1992).

12. Lakshmi, Majeti Jaya. Microteaching and Prospective Teachers. Discovery Publishing House Pvt. Ltd. Sachin Printers New Delhi, 12 (2009)

13. Barmawi \&M. Arifin. Microteaching: Teori Praktek Pengajaran yang Efektif \& Kreatif. Jogjakarta: Ar-Ruzz Media, 46 (2015)

14. Allen, Dwight., Kevin Ryan. Microteaching. Addison-Wesley Publishing Company Inc. Reading, Massachusetts Menlo Park, California, 26 (1969)

15. Lakshmi, Majeti Jaya. Microteaching and Prospective Teachers. Discovery Publishing House Pvt. Ltd. Sachin Printers New Delhi, 54 (2009)

16. Sukirman, Dadang. Pembelajaran Microteaching, Jakarta: Direktorat Pendidikan Agama Islam, Kementerian Agama RI, 27 (2012)

17. Lakshmi, Majeti Jaya. Microteaching and Prospective Teachers. Discovery Publishing House Pvt. Ltd. Sachin Printers New Delhi, 55 (2009)

18. Singh, Shivpal. Teacing Competency Through Microteaching Aproach, 75 (2011)

19. Allen, Dwight., Kevin Ryan. Microteaching. Addison-Wesley Publishing Company Inc. Reading, Massachusetts Menlo Park, California, 86 (1969)

20. Gall, J., Borg. W., \& Gall, M. Educational research: An introduction (7th ed.). Boston: Pearson Education, 187 (2003).

21. Emzir, Metodologi Penelitian Pendidikan,PT. Raja Grafindo, 105 (2008) 